\title{
Koroško mežiško narečje v luči novih glasoslovnih raziskav ${ }^{1}$
}

\author{
ZINKA ZORKO \\ Univerza v Mariboru, Filozofska fakulteta, Koroška cesta 160, \\ SI-2000 Maribor, zinka.zorko@uni-mb.si
}

\begin{abstract}
$\mathrm{V}$ razpravi so predstavljene nove glasoslovne raziskave koroškega mežiškega narečja. Na Javorju, v Črni in Mežici so se dolgi dvoglasniki poenoglasili, v Kotljah in Pamečah je ohranjen značilni koroški dvoglasniško-enoglasniški sestav, na Ojstrici je ohranjeno podjunsko narečje, mislinjski govor pa ima štajerski južnopohorski samoglasniški sestav.
\end{abstract}

This paper presents new phonological studies of the Carinthian Mežica dialect. In Javorje, Črna and in Mežica, long diphthongs changed into monophthongs; Kotlje and Pameče retained the typically Charinthian diphthongal-monophthongal system, Ojstrica retained the Podjuna dialect, and the Mislinja local dialect has the Styrian vowel system typical of southern Pohorje.

Ključne besede: koroško mežiško narečje, južnopohorski štajerski govor, glasoslovje, oblikoslovje, besedje

Key words: Carinthian Mežica dialect, Styrian local dialect of southern Pohorje, phonology, morphology, vocabulary

0 Za koroška narečja so značilni vsi splošnojužnoslovanski in splošnoslovenski razvoji in inovacije, ki jih je oblikujoči se slovenski jezik izvedel, odkar so se naši predniki naselili v Alpah, na Krasu in v Panoniji. Iz končnega praslovanskega vokalnega sistema: $i, y, u, b, b, e, o, Q, e, \ddot{a}, a$ je nastal na severozahodu dolgi vokalni sistem: $i, u, e e$, , oo, $e, a, e, Q$ ter kratki: $i, u$, ə, $e, o$, eä, $e, Q$; in iz teh dveh sistemov je nastal v prvi polovici 14. stoletja osnovni koroški vokalni sistem: $i, u$, iẹ, uo, e, e, $o, e^{1}, e^{2}, o+e, Q$, a ter kratki: $i, u, \partial, e, a, e, Q, a$.

${ }^{1}$ Besedilo je napisano s fonetičnimi znaki za knjižni jezik. Tako ostrivec pomeni dolžino, krativec kračino, pika pod $e$ in $o$ označuje ožino vokala, če pod $e$ in $o$ ni znaka, pomeni, da sta vokala široka. Polglasnik ima znak o. 
Najpomembnejši pojavi so:

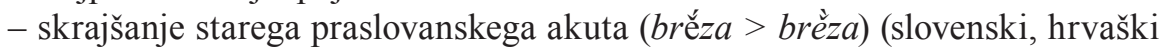
in srbski pojav);

- metateza likvid iz 8. stoletja, ki je v koroščini enaka kot v vsej južni slovanščini (melti $>$ mlěti);

- prehod $d^{\prime} \mathrm{v} j$ (pręd'a > preja);

- izenačitev praslovanskega trdega in mehkega polglasnika ( $p b s b>p \partial s, m ъ h ь$ $>m \partial h)$ iz 9. stoletja;

- izenačitev psl. $y$ in $i$ in prehod v slovenski $i(r y b a>r i b a)$;

- depalatalizacija soglasnikov pred sprednjimi samoglasniki;

- naglasna premika dušà > dúša, zlâto > zlatô, öko > okô;

- podaljšanje kratkih novih in skrajšanih starih akutov v nezadnjih besednih zlogih;

- razvoj zlogotvornega $t_{\mathrm{V}} \mathrm{v}$ ou;

- prehod $-t>-\underline{u}$

- ohranitev $o$-jevske barve za praslovanski nosni $Q$.

V koroških narečjih so se uveljavile tudi ožje slovenske inovacije: - razmeroma stara (12.-13. st.) je diftongizacija praslovanskega jata v ie, o v uo, na koroškem slovenskem ozemlju pa sta se ta dva diftonga razvila naprej v iə, uə.

Koroška narečja so dolgo ohranila nosnika $e$ in $Q$ ali pa je denazalizacija potekala pozneje kot drugod, lahko pa so nazali v posameznih govorih še ohranjeni.

Vokalizacija polglasnika v slovenskih dolgih zlogih ve (den, meh, len) druži koroška narečja s štajerskim in panonskim ozemljem.

Pozno so se podaljševale nezadnje besedne naglašene kračine (kot ob zgornji Savinji in na Pohorju), zato se tod pojavljata po dva različna refleksa za nekdanji praslovanski jat, $e$ in o (brẹ́za, zẹlle, vọ́la).

Prehod $ł a \mathrm{v}$ ua/wa je koroški pojav in prav tako tudi sekundarna palatalizacija velarov pred sprednjimi samoglasniki (swama, čita $<$ kita, muše $<$ muhe, druji $<$ drugi).

Samo lokalno koroški pa so pojavi: prehod $n j>j, l j>l$, labiovelarizacija $a$ $>o$ (Podjuna, severnopohorsko-remšniško narečje pa tudi nekatera štajerska narečja).

Umik dolgega cirkumfleksa zlasti z zadnjega besednega zloga za zlog proti začetku besede (zlatô > zláto); pojav je znan tudi v mežiškem narečju.

Lokalno koroški je razvoj nosnega $e$ prek nazaliziranega $a n \mathrm{v} a$ in vzporedno tudi razvoj dolgega polglasnika (trasem, vas, mah).

Koroški govori poznajo tudi naglasni pomik dolgega akuta na naslednji zlog: bábica > babíca, repíca; kazalni zaimki in prislovi se v koroščini okrepijo s poudarjevalno členico $\check{s}(e)$ : š̀̀ti, štàk.

Ziljsko, rožansko, obirsko in podjunsko narečje v Avstriji pozna kvantitetna in tonemska nasprotja, podjunsko na Strojni, mežiško ter severnopohorskoremšniško narečje v Republiki Sloveniji pa je izgubilo nizko intonacijo, torej akut, ohranila in posplošila se je visoka intonacija - torej cirkumfleks. 


\section{Govori v Mežici, Črni in na Javorju}

Na Karti slovenskih narečij (1983) so označeni kot govori mežiškega narečja, ki od Javorja proti jugovzhodu - proti Razborju - prehaja v severni del srednjesavinjskega štajerskega narečja.

Zgodovinski, zemljepisni in socialni vzroki so vplivali na poseben glasoslovni razvoj teh govorov, saj ne poznajo dvoglasnikov, tipična koroška diftonga í in $u$ ú sta se namreč zaradi štajerskih diftongov ej in ou poenoglasila v ozka é in ó.

Ostaja pa koroški naglasni sistem z vsemi drugotnimi in terciarnimi umiki in koroškim premikom v tipu babica ter koroška padajoča besedna melodija. V Mežici in Črni je še ohranjen prehod $-\nmid a-\mathrm{v}-w a-$ - torej švapanje, na Javorju pa tudi ta pojav izginja.

Gradivo za naglasne pomike: màgwa, stàza, kòsti, zlàto, òko, wàlka, zànas, pàrnas; babíca, repíca, wedẹli.

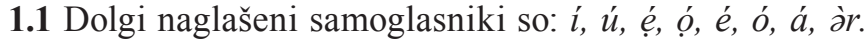

Dolgi $i$ zastopa stalno dolgi, akutirani in umično naglašeni $i$ : líst, píšem, swína, zíma; híša, lípa, ríba; cwílwa, písawa, zíbawa.

Dolgi $u$ je refleks za cirkumflektirani, akutirani in umično naglašeni $u$ : dúša, kúra, lúč, krúha, kúpwa, stúdenc, túlwa.

Dolgi ozki $e$ je zelo pogost vokal, saj zastopa dolgi in akutirani jat, dolgi in akutirani nosni $e$, dolgi in novoakutirani $e$ ter dolgi in novoakutirani polglasnik.

Gradivo: bẹu, grẹh, lẹp, mlẹko, swẹca, zvẹzda; brẹza, cẹsta, lẹto, mẹsto, nevẹsta, strẹha; pẹst, pẹt, pẹtek, plẹsem; dẹtla, poklẹknt, zẹt; lẹe, mẹ́d, pẹc; mẹčem, nẹsu, sẹdn, usẹéte, zẹle; dẹn, wẹs, mẹša.

Dolgi ozki o je odraz za dolgi cirkumflektirani in novoakutirani $o$, za cirkumflektirani in staroakutirani nosni $Q$.

Gradivo: bọ́h, mọč, nọč, rọ́h; (slišati pa je tudi úə: šúzwa); dọta, họja, nósim, prọ́sim, wọla; drọg, klọp, krọg, rọ́p, sọ́d; dọga, gọ́ba, kọ́ča, tọca strọ́k.

Dolgi široki $e$ je naslednjik umično naglašenega $e$ : ćélo, nésem, rékwa, téta, žéna; zélen; redko se pojavlja kot refleks nosnega $e$ v kratkem nedoločniku: začét, zapét.

Dolgi široki $o$ zastopa umično naglašeni $o$ in novoakutirani $o \mathrm{v}$ edinem zlogu: kóza, nóga, ósa, róka; kóš, króp, škóf.

Dolgi $a$ zastopa cirkumflektirani in akutirani dolgi a: ápno, dwá, grád, hrást, práh, kráwa, máti.

Samoglasniški or se izgovarja kot v knjižnem jeziku: párst, smárt, sárce, wárt.

V soglasniškem sestavu se pojavljajo naslednje premene:

- rinezem: mésnc, pájenk, wẹnč;

- švapanje se pojavlja redkeje, večkrat imajo besede dvojnico: šłà/šwà, dełáli/ dẹvali;

- slišati je tudi izgovor trdega $\ell$ kot vpliv štajerskega narečja, zlasti pri starejših govorcih: błò/bwò, kríło/kríwo, túč/wúč, márzło/márzwo;

- -šč- se olajša v -š-: ogníše, íšem. 


\section{2 Šentanel}

Šentanel leži na južnih obronkih Strojne in nad Podjuno v Mežiški dolini (688 metrov nadmorske višine). Vas je dobila ime po farnem patronu sv. Danijelu, ki se v listinah prvič omenja leta 1437. Danes spada v Občino Prevalje. Kraj je bil naseljen v 12. in 13. stoletju, saj je naseljevanje potekalo tod mimo, iz Mislinje prek Mežiške doline v Podjuno in naprej na Koroško po nekdanji rimski cesti.

Fran Ramovš je to narečje imenoval mežiško-koroško narečje s štajerskimi elementi (izguba intonacijskih opozicij). Med govoroma Šentanela in Strojne (podjunsko narečje) je velika razlika, verjetno zaradi farne meje. Tine Logar uvršča Šentanel nad Prevaljami v podjunsko-mežiški govor. Obsega Belšak, del Dolge Brde, Jamnico, Šentanel, Suhi Vrh.

2.1 Dolgi naglašeni samoglasniki $i, u ́$, í, úz, é, ó, é, ó, á, ór imajo naslednji izvor: $i$ je nastal iz izvornega $i$, $u$ iz izhodiščnega $u$, dvoglasnik $i$ 's polglasnikom v drugem delu diftonga) je naslednik cirkumflektiranega jata in dolgega etimološkega $e$, ú (s polglasnikom $\mathrm{v}$ drugem delu diftonga) je nastal iz dolgega etimološkega $o$, dolgi ozki é je odraz staroakutiranega jata in novoakutiranega $e$, dolgi ozki ó je naslednik novoakutiranega $o$ in nosnega $Q$, široki $e$ umično naglašenega $e$, široki $o$ je nastal iz labializiranega $a$, lahko pa je $a$ iz dolgega polglasnika in dolgega nosnega $e$, dolgi $a$ iz kratkega ali umično naglašenega $a$. Samoglasniški $r$ se izgovarja s polglasnikom pred $r$.

Kratki naglašeni samoglasniki so možni v zadnjem ali edinem zlogu, zaradi starejših in mlajših umikov pa tudi sredi besede. To daje slušnemu vtisu govora ritmično razgibanost. Kratki a je slišati tudi za umično naglašena polglasnik in nosni ę: màgwa, pàsa, màso.

$\mathrm{V}$ soglasniškem sestavu ne najdemo rezultatov koroške sekundarne palatalizacije, velarni $\ell$ se pred $a, o, u$ izgovarja kot $w$ (wúč, wáhko).

\section{Kotuljski govor}

V vasi Kotlje in okoliških zaselkih: Podgora, Preški Vrh, Brdinje se govori mežiško narečje, kakršno je predstavljeno v Ramovševih in v Logarjevih razpravah. $\mathrm{V}$ večjih sosednjih naseljih in mestu Ravne na Koroškem domačini ohranjajo temeljni koroški glasovni sestav, slišati pa je tudi nadnarečni jezik, saj se je prebivalstvo zlasti v 20. stoletju zelo mešalo, priseljevanje iz drugih slovenskih pokrajin se je po letu 1920 povečalo, zlasti pa po letu 1945 se je prebivalstvo povečevalo tudi na račun priseljenih delavcev v mežiškem rudniku in v Železarni na Ravnah iz drugih republik. Nekaj časa so prihajali na Šolski center dijaki iz Bosne, da so se izučili za metalurške poklice. Večina se je vrnila v matične tovarne, nekaj pa jih je ustvarilo novo družinsko gnezdo na Koroškem.

Kotuljski govor je izgubil intonacijske opozicije, ohranjen je le padajoči, visoki naglas na katerem koli zlogu besede. Naglašeni zlogi so dolgo naglašeni, kratko naglašen je lahko ostal zadnji ali edini zlog besede, kratki pa so 
lahko tudi drugotno naglašeni zlogi zaradi mlajših naglasnih umikov. Tako se ustvarjata posebna ritmika besede in melodična stavčna zgradba; po ritmu in melodiji prepoznamo rojenega Kotuljčana - Korošca, četudi se prilagaja knjižnemu glasovnemu sistemu.

3.1 Dolgi naglašeni samoglasniki so: $i$, ú, í, úə, é, ó, éleá, ó/oá, á, ár. Izvor:

- $i$ je nastal iz dolgega cirkumflektiranega in akutiranega $i$ : líst, píšem, zíma, zit; híša, lípa, ríba, žila;

- ú je nastal iz dolgega cirkumflektiranega in akutiranega $u$ : lúč, lúpim, lúbje, olúp;

- dvoglasnik ía zastopa cirkumflektirani jat in dolgi etimološki e: gríah, lís, slíap; líat, píač;

- dvoglasnik ú je odraz za dolgi etimološki o: búəh, múəč, núəs;

- dolgi ozki é je naslednik dolgega polglasnika: wẹs, dẹn, lẹn, mẹ́h; dolgega nosnega e: glẹda, pẹt, zẹ́be; staroakutiranega jata: brẹza, césta; novoakutiranega $e$ : nẹso, pẹ́ko, rẹ́ko;

- dolgi ozki ó je odraz za dolgi nosni $Q$ in novoakutirani $o$ : kwọ́p, rọ́p, sọt; xọja, nọsim, škọ́da;

- dolgi široki e z varianto eá je naslednik umično naglašenega $e$ in staroakutiranega jata v trozložnicah: nésem, žéna; deáwat, meátat, reákwa, reázat;

- dolgi široki ó z varianto oá je nastal iz umično naglašenega $o$ in novoakutiranega $o \mathrm{v}$ zadnjem zlogu: kótu/koátu, kózalkoáza, oása; čoák, koášs, poát, stroák;

- dolgi a je naslednik etimološkega $a$, redko tudi polglasnika: dwá, grát, král, práh; část;

- samoglasniški r se izgovarja s polglasnikom pred $r$ : sárce, smárt, párt.

3.2 Kratki naglašeni samoglasniki $i, u, e, o, a$ in $ə$ so nastali iz izhodiščnih kratkih samoglasnikov ali pa so postali naglašeni po naglasnih umikih v zadnjih stoletjih. Slišimo jih zlasti v oblikah knjižnega mešanega naglasnega tipa: núač - nòči, píă - pèči, líat - na lèdu, búax - x bògu, čròwo iz črevó, jàme iz imé; pèkwo : péčem; v oblikah premičnega naglasnega tipa: wèčer, wùho, zelo pogost je kratki naglašeni polglasnik, ki je nastal iz kratkega polglasnika, umično naglašenega $e$ in kratkega $i$ : ḋ̀š - dàža; sàno, dràwo; càgan, màš, nàč, tàc, ż̀t. Kratki $a$ je tudi zastopnik kratkega polglasnika in umično naglašenega nosnega ę: bàdet, màgwa, pàku, pàs, stàbər; màso.

Nenaglašeni samoglasniki se lahko reducirajo do stopnje polglasnika, onemevajo, nekatere pripone, npr. -əc-se izgovarjajo kot -oc: góboc, koásoc.

$\mathrm{V}$ soglasniškem sestavu je najbolj opazno t. i. švapanje, to je premena nekoč trdega $t$ pred samoglasniki $u, o, a$ in zvočnikom $r \mathrm{v} w$ : bwágo, díwawa, kwóp, meátwa. Narečje ne pozna ustničnozobnega $v$, govori se le dvoustnični w: wága, wéra, wíno, wùho. Končni zveneči mehkonebni g izgubi zaporo in se izgovarja $h$ : búzh, núzh, rúzh, sníh, wráh. Samoglasniški ł se je razvil v ou: bóuha, wóuk, wóuna. Kot rinezem se pojavljajo oblike: mísñc, pájenčna, 
vénč. Znano je štekanje: šták, š̀̀ti; štàm, štọdi. Palatalni lj otrdi: púzle, $n j$ se razvije v $n, j$ : svína in svija. Sklop šč se asimilira v -š-: gọ́ša, pàše.

\section{Govor na Ojstrici nad Dravogradom}

Na Logar-Riglerjevi Karti slovenskih narečij (1983) je govor Ojstrice vrisan kot sestavni del mežiškega narečja. Natančna analiza tega govora na glasoslovni, oblikoslovni in besedijski ravnini kaže, da je to podjunsko narečje, podobno podjunskemu narečju na Strojni, saj se tudi na Ojstrici razvije dolgi polglasnik skupaj z nosnim $e$ v $a$, torej gre za pozno denazalizacijo in za skupen razvoj s polglasnikom. Tudi dolgi $a$ se labializira v široki $o$. Takega razvoja $a$-ja pa mežiško narečje ne pozna. Podoben razvoj je potekal v Dravogradu, na Viču in čez Dravo v Libeličah.

Tonemska nasprotja so se tudi na Ojstrici izgubila, naglas je le padajoč, naglašeni pa so dolgi in tudi kratki samoglasniki.

4.1 Sistem dolgih samoglasnikov sestavljajo: $i$, ú, ì, úə, é, ó, é/eá, ó/oá, á in ár. Navaja se gradivo za tiste samoglasniške odraze, ki se ločijo od kotuljskega mežiškega govora.

Za staroakutirani jat se pojavljata dva odraza, široki eá in pred zlogom z -i- ozki é.; verjetno gre za vokalno harmonijo: breáza, ceásta, deáwati, leáto, žiweáwa; bedeáwa : bedẹli, boleáwa : bolẹli, jeádwa : jẹdli, kleáwa : klẹli, peáwa : pẹ́li. Za novoakutirani e je slišati tudi dva refleksa, eá in ẹ: mẹlem, zẹ́le; neáso, peáko, reáko.

Za novoakutirani $o$ je slišati dva refleksa: ozki $o$ tako kot za dolgi nosni $Q$ pa tudi široki oá kot za umično naglašeni o: họdim, mọdlim, nọsi, họ́dwa (ž. sp.); coáta, koáža, roáža, škoáda, groáp, koáš.

Dolgi široki $o$ zastopa večino praslovanskih dolgih $a$ tako kot v podjunskem narečju: dówa, dwó, hwópoc, król, mó/móde (ima), póst (namenilnik, nedoločnik je pást).

Samoglasnik $a$ zastopa dolgi etimološki $a$ v določeni glasovni soseščini, večino stalno dolgih in staroakutiranih nosnih $e$, dolgi polglasnik, novoakutirani polglasnik v nezadnjem besednem zlogu in kratki naglašeni $a$ : $-a u$, -awa, -wa: bəršáuka 'brisača', gwáwa, kráwa, práu, pwáwa, orjáwi, tráwa, zdráu; -aj: bájbika, bájta, prájli; -ra, -ar: bárt, bráda, pár, Ármeu; -an: Ánika, dwán, sántər, tántor.

Za nosni ę so primeri: jáziu se je, jázna, pátok 'petek', potáni 'potegni', prádem, sádi! 'sedi!', stáni se 'stegni se', wnále so se, ta wáči dwó, uzáu, zábwo, zác, začáli, zavázali, dekláta, jonáta 'juneta', pišáta, teláta, žrebáta; imána, semána, wremána; dán, máh, wás, máša, páhne, premákne, wážem; brát. Ker se $l$ pred $a$, nastalim iz nosnega $e$, ne premenjuje $\mathrm{v} w$, kaže, da je bil nosni $e$ ohranjen prek časa kot $e$-jevski vokal, ko se je v koroščini razvijal $t$ pred $a, o, u \mathrm{v} w$, torej $\mathrm{v} w a, w o, w u$, vendar ostane -le-, ki se je kasneje skupaj $\mathrm{s}$ polglasnikom razvil $\mathrm{v}-l a-$. 
4.2 Kratki naglašeni samoglasniki so na Ojstrici naslednji: ì, ̀̀, èlè, òlò, $\partial, a$. Od kotuljskega govora se razlikuje ta sistem pri naslednjih pojavih:

- dolga $i$ in $u$ se lahko skrajšata pred zaporniki; ta pojav se nadaljuje tudi $\mathrm{v}$ remšniškem narečju;

- kratki naglašeni polglasnik je lahko odraz za kratki sekundarno in terciarno naglašeni $i$ pa tudi za $e$ in jat po samoglasniškem upadu: màš, jàdi, jàspa 'podstrešje', màne, oblàčt;

- kratki naglašeni $a$ je naslednik kratkega sekundarno ali terciarno naglašenega $a$, sekundarno naglašenega $e$ in polglasnika: bràt, zàčne; màdwa, màhki, màso; màgwa, pàku, pàs.

V soglasniškem sistemu je na Ojstrici znano koroško švapanje, prav tako pa tudi izgovor dvoustničnega $w$.

\section{Govor v Pamečah pri Slovenj Gradcu}

V Mislinjski dolini so ob Mislinji večji kraji: Otiški Vrh, Šentjanž, Pameče, mesto Slovenj Gradec, Šmartno, Mislinjska Dobrava in Mislinja.

Predstavljena bosta govor Pameč v predmestju Slovenj Gradca, ki kaže v glasoslovju tudi prehodne pojave med koroščino in štajerščino, in govor Mislinje, ki je že štajerski govor, in v njem slišimo le še redke sledi koroških razvojev, zlasti v naglašanju besed in v besedni melodiji. Jedro naselja Pameče je okrog neogotske župnijske cerkve svetega Jakoba, ki se prvič omenja leta 1488, soseska Nova vas pa se povezuje s Trobljami.

Pameški govor je izgubil intonacijsko nasprotje, besedni naglas je le padajoč. Izvršeni so vsi vzhodnokoroški naglasni pomiki: žéna, nóga; mégla, stéza, òko, zlàto, babíca, palíca.

5.1 Dolgi naglašeni samoglasniki so: $i$, ú, ís, úə, é, ó, é, ó, á in ár. Zastopajo iste izvorne samoglasnike kot v kotuljskem govoru, le da se umično naglašena široka $e$ in o ne zatezata v dvoglasnik eá, oá: kóza, nóga, ósa, kóšs, pód; čélo, nésem, téta, žéna.

Posebnost govora je tudi variantno se pojavljajoči široki $e$ za staroakutirani jat: powédat, rézat; to je lahko vpliv severnopohorskega narečja.

5.2 Kratki naglašeni samoglasniki $\grave{i}, \grave{u}, \grave{e}, \grave{o}, \grave{a}$ in $\grave{~}$ so lahko nastali iz akutiranih samoglasnikov v edinem ali zadnjem zlogu besede, po drugem ali tretjem naglasnem umiku pa tudi sredi besede.

Gradivo: sìt, wìgred, blì, šlì; kùpčat, pùklast, trùgla; kmèta, smèjat se; kònc, zòbi, wòda; òko, šòrek; iz kratkega u: čòt, kòp, kròh, skòp, štò; dòšit, sòšit; bràta, gàd, nàs. Kratki naglašeni polglasnik je lahko nastal iz kratkega $i$ : mòš, nàč; iz $i$ po terciarnem naglasnem umiku: càgan, žàwo; iz umično naglašenega $u \mathrm{v}$ besedi làdi; iz glagolskih osnov pred končajem - ̌́t: slàčt, pàčt, ràčt, ostràčt; iz kratkega, umično naglašenega $a$ : $k \grave{k}$, tàk. 
Samoglasniški upad se pojavlja ob zvočnikih in v končaju nedoločnika: žwina, máš, blà, místot, bábnca.

Soglasniški sestav se od kotuljskega razlikuje le po izgubi prehajanja -ła $\mathrm{v}$ -wa, torej govor ne pozna več švapanja: délat, cikláma, lúna. Druge soglasniške premene so: -nj- > -j-, -n-: čarpíja, kúaj, kostája, čríašna, lúkna; -lj-> -l-: klúč, král, wọ́la, zẹle; mẹlem, pẹ́lem; -vi- > -j-: prájla, sprájla; proteza j: jàdi, jàme; $v$ se izgovarja dvoustnično: žàwo; wmòt, wpòt; proteza w-: wòni; ohranjena je skupina -dl-: mòdtlt, wẹ́dla rọ́ža.

\section{Mislinjski govor}

Na Karti slovenskih narečij (1983) je vrisan mislinjski govor na vzhodni meji mežiškega narečja ob srednjesavinjskem in južnopohorskem narečju. Gre torej za vmesni govor med koroško in štajersko narečno skupino, ki je zlasti bistveno vplivala na današnjo jezikovno podobo mislinjskega govora.

Kraj Mislinja se prvič omenja 1335. leta kot del slovenjegraškega gospostva. Od leta 1998 je Mislinja občina, ki obsega gornji del Mislinjske doline in na 122 $\mathrm{km}^{2}$ živi 4600 prebivalcev. Razvoj kraja se je začel s fužinarstvom. Fužine so začele obratovati leta 1724 in 1754 so prešle v last Michelangela Zoisa, podedoval jih je sin baron Žiga Zois. Rudo so kopali na Pohorju, v okolici Vitanja, oglje pa so žgali v gozdovih visoko nad Mislinjo. Prvo visoko peč je imela Mislinja leta 1762. Lesna industrija je nastala po letu 1900: žage, tovarna lepenke, sodarna, zabojarna. Do danes sta ohranjena še žaga in nasad eksotičnih dreves.

V občino Mislinja spadajo zaselki Vovkarje, Straže, Movže, Šentlenart, Sejmišče, Prisoje, Šolska, Gozdarska in Pohorska cesta. Že iz antičnih časov je znan promet skozi Mislinjo v Stari trg in na Gospo Sveto, v srednjem veku pa se je po cesti Slovenske Konjice - Vitanje - Straže - Slovenj Gradec razmahnilo tovorništvo. Kraj Mislinja nosi ime po reki, desnem pritoku Drave, dolgem 36 km. Poleg tega imena se pojavlja tudi oblika Mislíje - v srednjem spolu.

\subsection{Naglasne razmere in glasoslovje}

Mislinjski govor pozna jačinsko naglaševanje. Narava tonskega poteka je padajoča, naglašeni zlog je visok. Mesto naglasa je po naglasnih pomikih dokaj različno, naglašen je lahko kateri koli del besede. Samoglasniški sistem pozna dolge enoglasnike in dvoglasnike, kratke enoglasnike in nenaglašene vokale. Poleg splošnih slovenskih naglasnih pomikov pozna govor koroški premik na desno: babica, pisánka, pa tudi koroško-štajerski umik na levo. Kratki naglašeni samoglasniki sredi besede kažejo na mlajše naglasne umike.

Gradivo: buógat 'bogat', smo dóubli, govọ́rli, uótrok 'otrok', kọsit, uótprit, sọsit, vòho, živo. Pogosto se sliši kratki naglašeni polglasnik, za $e, i$, o: càgan, bàt 'biti', jàt 'iti', nàs 'nesi', na bràgu, màso, nàbo, tàt 'toti', vàdet 'videti'. 
Umično naglašeni $o$ se je razvil v dvoglasnik uó, umično naglašeni $e$ pa $\mathrm{v}$ dvoglasniški eé ali široki e: kuósa, téta, žeéna.

Dolgi samoglasniki: ílíj, ú (redko tudi úu), é, ó, éj, óu, é/eé, ó/uó, á, ár so nastali iz starih cirkumflektiranih samoglasnikov in starih skrajšanih in pozneje podaljšanih starih in novih akutiranih samoglasnikov sredi besede. Podoben samoglasniški sistem zasledimo v južnopohorskem in severnem srednjesavinjskem štajerskem narečju (zatezanje dolgih $i$-jev in $u$-jev, diftonga ej za $e$ in $e$ in ou za etimološki $o$ in t, dolgi ár za samoglasniški $r$ ). Na tak razvoj kažejo tudi pojavi parazitskega $j$ in sekundarne nazalizacije.

Izvor:

Dolgi $i$, ki se lahko zateza tudi v íj, zastopa stalno dolgi $i$ : líst, píšem, svíja, zíma; líjst, síjto; staroakutirani $i$ : híša, lípa, ríba, žíla. Slišati pa je tudi kratek izgovor $i$-ja in to daje akustični vtis zasekanosti.

Dolgi $u$ (tudi $u ́ u$ ) zastopa dolgi cirkumflektirani in staroakutirani $u$, lahko pa se tudi skrajša, podobno, kot je to slišati pri vokalu $i$ : lúč (tudi lúuč), lúpim, krúha, kúpa.

Dolgi ozki é je refleks za staroakutirani jat, za stalno dolgi nosni ę, za dolgi polglasnik in za novoakutirani e: brẹza, cẹsta, lẹto, mẹsto, nevésta; glẹdam, pẹt, plẹsem, prẹdem; dẹn, mẹh, vẹs; mẹsa, pẹsji, premẹkne; nẹso, pẹ́ko, rẹko, zẹle.

Dolgi ozki ó je odraz dolgega nosnega $Q$ in novoakutiranega etimološkega o: klọ́p, otrọ́bi; gọ́ba, tọ́ča; nọjsim, škọda, vọ́la.

Dolgi dvoglasnik éj zastopa stalno dolgi jat in dolgi cirkumflektirani etimološki e: léjs, mléjnko, svéjča, sméjh, zvéjzda; léjt, péjč.

Dolgi dvoglasnik ó u je refleks za dolgi cirkumflektirani $o$ in za dolgi samoglasniški l: bóug, móunč, nóunč, róug,; čóun, dóug, vóuk, žóuna.

Široki é (lahko tudi diftongični eé) zastopa umično naglašeni $e$ in kratki naglašeni polglasnik čélo/čeélo, nésem, rébra/reébra, tétalteéta, žéna/žeéna; peés/pés.

Široki ó je odraz za stalno dolgi $a$; to je tipično štajerski in koroški podjunski pojav, medtem ko ga koroško mežiško narečje ne pozna: dvó, hróst, kovóč, ópno, próh.

Dvoglasnik uó zastopa umično naglašeni $o$ in novoakutirani $o$ v edinem zlogu: kuóza, uósa, kuóš, kruóp, puót, škuóf.

Dolgi a zastopa $a$ ob $r$ in staroakutirani a: bráda, grád; bráta, nás.

Samoglasniški $r$ se izgovarja kot dolgi ar: cvár, čárn, dár 'drl', smárt.

6.2 Kratki naglašeni samoglasniki so $\grave{i}, \grave{u}, \grave{e}, \grave{\partial}, \grave{o}, a$.

Redko so nastali iz starih in novih akutiranih samoglasnikov: žila, krùha, kùp, pàko 'pekel', nàs 'nesi', tàt 'toti', nàt, màš, tàk, kàk, vzàmi, vọ̀s 'uš', sọsit, màgo 'mogel', vmràt, vpàt; največ je primerov z upadlim kratkim $i$, ki se pogosto izgovarja polglasniško: jàt, jàdi, bàt, vbàt. Večinoma so nastali po moderni vokalni redukciji iz $e, o, u, a$. Nenaglašeni vokali so dobro ohranjeni. Zlogotvorni ł: gréjbłca, šórkł, núdtci je pogost v prevzetih besedah. 


\subsection{Soglasniške premene}

Soglasniški sestav se bistveno ne razlikuje od knjižnega. Narečne premene so: - končni - $l$ se lahko izgovarja kot dvoglasniški u/u: -ál >báu, -al > dẹlou, -iu $>$ sušíu, -ul > obú, čú ( $u$ onemeva), -al se razvije v o > néso;

- palatalni lj je izgubil mehčanost: król, stẹla, vọla, zẹle, zémla;

- zlogotvorni $t$ ima odraz -ou: dóug, póuh, tóučt, vóuk, vóuna, žóuna;

- skupini črě-, žrěe-sta ohranjeni: črejšna, žgràbł/žgràbu, žrébe;

- v besedi z nosnim $n$ se pojavlja sekundarna nazalizacija: mléjnko, mónka, móunč, nóunč, snéjnk; to je tipično štajerski južnopohorski pojav; -enk je tudi pripona za -ek in -ik: močerádjenk;

- palatalni $n j$ sredi besede izgubi nazalni element, na začetku besede, za soglasnikom in na koncu besede pa palatalni element: kaméje, svija, znaméje; níva, lùkna, ójgn/vójgn;

- zvočnik $v$ se izgovarja kot zobnoustnični $v$ pred samoglasniki: svíja, víno; čréjva; na koncu zloga ali na koncu besede se izgovarja dvoustnično: udóu, pojavlja pa se tudi kot proteza pred $u$ - in $o$-vùšlvòs, vòho, vuòkno, vọjgn, vọna, vuóreh, le v besedi 'iva' je slišati protezo g: gíva;

- zvočnik $j$ se izgovarja kot pripornik pred samoglasnikom, za njim pa kot dvoglasniški - $i$ (pišem ga kot $j$ ); značilno štajersko je vrivanje parazitskega $j$ pred $d, g$, s: họjdim, tújdi; vọ́jgn, ọjstro, trọjsit;

- sklop -šč- se olajša v -š-: gọśsa, kléjše;

- ohranjena sta sklopa -dl- in -dn-: mọdtt, jẹdla, mẹ́dnce kot v koroških narečjih;

- zveneči soglasniki na koncu besede izgubljajo zven: golọp golọba;

- končni -g se lahko izgovarja kot priporniški h: bóuh, próh 'prag';

- $k$ lahko nastane tudi iz $t$ : kẹdn, kẹ́kna, klóčit, trẹ́ki;

- -dn- prehaja v -gn-: gnár;

- na koroški vpliv kaže prehod -vi- v -j-: pràjim.

\subsection{Oblikoslovje}

V ednini so v mislinjskem govoru ohranjeni vsi trije spoli, nekateri samostalniki srednjega spola se feminizirajo že v ednini; v dvojini in množini so samostalniki moškega spola, tudi s podaljšano osnovo - $t$ - ali - $n$ - iz edninskega srednjega spola. Prevladuje nepremični naglasni tip, premični je redek, izgubila sta se mešani in končniški naglasni tip.

\section{$\underline{\text { Samostalniki moškega spola }}$}

Vzorec: mlín -ø - a -u -ø -u -am; dv. -a -ou -oma -a -ah-oma; mn. mlín -i -ou -om -e -ah-ami/-am.

$\mathrm{V}$ or. ed. je končnica -am. Govor ne pozna preglasa -o-v -e- za $c, j, \check{c}, \check{z}, \check{s}$. $\mathrm{V}$ imenovalniku množine govor ne pozna končnice -je, prav tako ne podalj- 
ševanja osnove z -ov: bráti, sini; tip pés/peés se sklanja: peésa ali psá; kratko naglašeni korenski samoglasnik se v pregibanju podaljša: krùh/krọh - krúha. Samostalniki moškega spola, ki se končujejo na samoglasnik ali zlogotvorni $l$, podaljšujejo osnovo z - n-, in sicer tako kot v nekaterih koroških narečjih: Márkona, Stánkona, Tómona, parjóttına, raunátłna; v prevzetih besedah: árkłna, pánttna. Samostalniki tipa 'lasje' se sklanjajo po vzorcu: lási - lási - lásom - lási - lásah - lásami ( lásam). Orodnik množine lahko izgubi končni - $i \mathrm{v}$ končnici - ami; v rodilniku ednine je pri starejših govorcih še ohranjena končnica -u-ród - ródu, tudi: dvó ródu.

Sledovi mešanega naglasnega tipa se po naglasnem umiku kažejo v naglašanju osnovnega zloga: bréjk bréga na bràgu. 2. in 3. moške sklanjatve govor ne pozna, 4. pa je enaka pridevniški.

Samostalniki ženskega spola se sklanjajo po enakem vzorcu kot v knjižnem jeziku, in to samo po nepremičnem naglasnem tipu: lípa/lìpa (krajšajo pred zaporniki - štajerski narečni pojav) líp - $a-e-i-o-i-o$; - $i$-ø -ama -i -ah -ama; $-e-\varnothing-a m-e-a h-a m i$. Samostalnika móti in čejra imata v tožilniku ednine obliko: mótero, čéjro.

Že v ednini se feminizirajo številni samostalniki srednjega spola, npr. rébra, čréjva, prav tako v množini vsi z nepodaljšano osnovo: jẹtre, plúče, úste.

V II. ženski sklanjatvi je prevladal nepremični naglasni tip, sledovi mešanega naglasnega tipa so v akcentuaciji: nóunč - nòči, péjč - pèči. Vzorec: màš -ø míši -i màš -i -jo; mn. mís -i -i -im -i -ah/-ih- -mi/-ami.

Samostalniki srednjega spola imajo posebno sklanjatev le v ednini, v dvojini in množini so ženskega ali moškega spola. Vzorec: mẹst -o - $a-u-o-u-o m$; mn. mẹste.

Skupna, pojmovna in snovna imena so v ednini srednjega spola: koréje, ogníše, mléjko, màso/meéso. Med moške samostalnike s premičnim naglasom prehajajo v dvojini in množini: téle-telẹta; dv. telẹta; mn. telẹti/télati; màče mačẹta; tako še bréme bremẹna; -a; bremẹni; sẹme semẹna; semẹni.

Samostalnik deékle deklẹta ima v množini obliko ženskega spola: deklẹte.

\section{$\underline{\text { Samostalniški zaimki }}$}

Osebni zaimki so: jàs/jàs, méne me, màni mi, méne me, par màni, z mẹno; tí, tébe te, tàbi ti, tébe te, par tàbi, s tẹbo.

Za tretjo osebo je lahko osebnozaimkovna sklanjatev wòn jéga/vònga, vọnadvó/vọnih iz oblike kazalnega zaimka, s predlogom v tožilniku pa zájnga, zájo. V dvojini so oblike: màdva, nóju, nóma, vàdva, vóju, vóma, v množini pa mí, nás. Vprašalna zaimka sta gdóu, kuóga, kó, čésa; oziralna sta enaka, màrsikdóu, màrsikáj sta poljubnostna, nikalna nobàdn, nàč. 


\section{Pridevniška beseda}

Pridevniki so kakovostni, vrstni, svojilni in količinski: léjp, strọjni, mámin. Pridevniška sklanjatev ima tudi v ednini tematski $i$ za moški spol, ženska sklanjatev je enaka knjižni. Vzorec: léjp - a -o; léjpiga, léjpimu, 2. ali 1., léjpem, léjpim; mn. léjp -i -ih -im -e -ih -imi. Stopnjujejo se z obrazili -ši, -ji, -ejši in opisno: léjp, léjpši -a -o; nízek, nižji; vàlek-vẹčji, stár, staréjši; bol léjp. Oblika ta vẹci pomeni tudi 'največji'.

Števniki so glavni: édñlèn, dvó, dvej, tríji, trí, štírji, štíri, pẹt, šéjst, sẹ́dn, ósn, devẹt, desẹt, dvájsti, tríasti, štárdeset, stóu, dvéj stóu, tàužnt.

Vrstilni so: párvi, drúgi, trẹki, štárti, pẹti, stóuti; množilni enọjn, dvọ́jn; ločilnih ne poznajo.

Pridevniški zaimki se sklanjajo po pridevniški sklanjatvi. Svojilni: mọj, tvọ́j, jegóu, jẹn, nójin, vójin, jójin, nóš, vóš, jàhou; svọj. Vprašalni: kó, kẹri, čigáu, čigóva, čigóvo. Oziralni: kókršen, kẹri. Drugi zaimki: nẹki, mársikók, mársikẹr, usók, nobén, drúgi, drúga. Kazalni zaimek: tàt, tọti, tísti, vọ̀ni. Oblika šàt/š̀̀ti kaže na koroški vpliv.

Glagoli so nedovršni in dovršni, prehodni in neprehodni, poznajo povedni, pogojni in velelni naklon, tvorni in trpni način, osebne in neosebne oblike. Nedoločnik je kratek, namenilnik ima redke posebne oblike: nedoločnik: póst, namenilnik žénem pást; scát, šóu je scót. Deležnik na -l poznajo vsi glagoli, trpna deležnika se končujeta na - $n$ ali - $t$ : nớjšen, zapít. Drugi deležniki so redki: bojẹć, gredọč, biuši. Glagolniki na -je: nọšeje, tepéje, žiuléje.

Spregatveni vzorec za sedanjik je samo priponski: dẹlat: déjlam, déjlaš, déjla; déjlama, déjlata, déjlata; déjlamo, déjlate, déjlajo; tako jéjta, jéjte, véjta, véjte; bòta, bòte; dóta, dóte; velelnik: déjlaj, déjlajma, déjlajta, déjlajmo, déjlajte; deležnik: dẹlau; sn dẹlau, bom dẹlau, sn biu dẹlau, bə dẹlau.

Med prislovi so zanimivi: górta, dóuta, vọnta, gdàj in kéda. Ob glagolih se uporabljajo kalki za pomene: gor, dol, noter, ven: nòtər pokuópat, gọr ustát, vàn potẹgnat (ob priponi -ni- se pojavlja tudi štajerska -na-), nazáj pròt.

Med predlogi, vezniki, členki in medmeti ni veliko narečnih odstopanj od knjižnega jezika.

\section{Besedilo v mislinjskem narečju (Pripoveduje Jože Oder)}

Že préjmar (prej) sn v šóulo šóu, sn ža mágu óuce pást. Dóma énih sẹdn, ôsn óuc pa par sọ́sedi énih sẹdn pa še króve zráuno, tak da sn mágu pást. To je blo duóčes, do šóule. Jàs sn ujùtro ob š̀̀stih, póu sàdmih gnáu pást, da sn napóso óuce sosẹdove no nóše. To je blò polẹti, pósli smo pa po gọ́ši. Pozími smo se sánkali, škijali se réče no, dáj prájo smúčali. Seéstre so mámi pomógale, pa sosẹdu so šleé tudi, pa kóka fižọla je blá za lúšit. Pa so blé za óhtat, Tọ́nka pa Sláuka je blá ta zódna. 
Navódno si méu éne léjpe šúhe, tàste si pač méu za círko. Za šóulo sn méu pa cọkle al pa gájbłne. Polẹti pa bóus. Sn méu sàmo éne hlóče za šóulo, jọpič pa kók polọvar, ko je máma zaštrikala. Pa rokavíce vounéjne, z domóče préje. Ko smo duóma óuce mẹli, smo pa skartóčli, usè sprẹdli duóma.

Pardéjlali smo duóma àrš, kurúzo, krompír/repíco, pa še néka je pšenìnce blọ. S króvo smo voróli, na rọke žẹli, na rọ́ke smo mlótli, pa vẹ́li tùt, tóka vijóča je bla. Pó smo pa nàsli v mlín, dáuči, éne trí do štíri kilomẹtre smo nàsli na rómi žito v mlín, pọl smo pa tàm mlẹli céjlo nóunč učós. Pọl drúgo jùtro smo pa nàsli nazáj al pa vàčer. Pa mlín smo mágli otslúžit, da smo làhko mlẹli: plét kàj pa kọsit, pa trọjsit pa u gọšo jàt von pràglat, drớve napráulat, pa léjs séjkat.

$V$ hiši je pa bla híša, štibłc, kúhna, pa lóupa. Na lóupi smo mẹli tók tộftpẹt. Nát sta ležóla bráta. Polẹti smo pa na góunu ležóli v sènu. Tùdi u štóli smo ležóli. Fọjtrali smo pa mlódo próprot, pa sárpje, pa krompir, kóke otrọ́be.

Za kovóča sn se navdúšo. Ko sn họjdo v osnóuno šóulo, sn vídou éno kovač́jo, sn vído, ko kújejo. To me je naudúšlo, ko je biu vójgn, pa ko so kowóli, ko so tóukli po àmpusu. Popráulam stóre sekíre, cipíne.

\section{Narečno besedje $v$ mislinjskem govoru (slovensko in prevzeto)}

àmpus 'nakovalo', ántuh 'brisača', ájnrikati 'vstopiti v vojsko'; áutarce 'naramnice'; bárčlan 'bršljan', britof 'pokopališče'; cigúra 'cikorija', cọta 'krpa', cígo 'opeka'; črámsa 'čremsa'; dọ́usa 'sem dol', déra 'pograd', dímanca 'dimnica', dile 'podstrešje'; évanka 'babica pri porodu'; finkslùkna 'kdor za binkošti zaspi', fižólika 'ženski spolni organ', fértik 'gotov', fájn 'dobro', fórbati 'barvati', fájcou 'ruta', firtuh 'predpasnik'; grúška, gọša 'gošča, gozd', glid 'sklep', giva 'iva', gneét 'gnjat', góuno 'gumno'; hẹlfer 'pomočnik'; jánka 'krilo', jám 'javor', jižina 'malica, tudi kosilo'; klínc 'klin', kẹtna 'veriga', kopárc 'igličje', kríspám 'božično drevo', kvartír 'stanovanje', kọčeki 'prašički', kikla 'krilo', knuóf 'gumb'; láufat 'teči', láger 'skladišče', lájbič 'telovnik', léjtance 'peruti'; močerádjenk, mẹ́dnce 'droži', móntt 'plašč'; núdtci 'rezanci'; póuštar 'blazina', pódo 'podel', pórmašina 'vrtalo', plòh 'hlod', páuri 'kmetje', pisánka 'velikonočno darilo', peép peéba 'fant', platič 'suho sadje', pàcek 'moški spolni organ', plọnt 'blond'; repica 'krompir', rọ́žnkrónc 'molek', rẹ́gł 'regrat'; snuóp 'butara', sinsvedi 'vsi sveti', šóuštar 'čevljar', špórhet ‘štedilnik', štúmfi 'nogavice'; šájba 'šipa', špricati 'škropiti', štàmpet 'postelja', šúhi 'čevlji', štibłc 'sobica', šàti, štàk, šták 'takšen', šráuf 'vijak', štalẹk 'kovani predmet', švásat 'variti', štrọ́zok 'slamnjača', štrájfat 'veti', štóla 'hlev', šọlni 'čevlji'; tífa 'endivija', trúga 'krsta', tọ́tnkómra 'mrtvašnica'; vẹ́s 'perilo'; zọtlar 'sedlar', zakumrón 'zaostal v rasti', zọ́s 'omaka'; zíza 'dojka'; žùpa 'juha', žégnpaj, žégn 'blagoslov'; žnídar 'krojač'.

\section{Značilnosti štajerskega zreškega govora}

Mislinjski govor meji na vzhodu na štajersko južnopohorsko narečje, na jugu pa na srednjesavinjsko narečje (vzorec: Zreče, Gaberke). 
Za južnopohorsko narečje, ki se po Logarju (1983) govori od Doliča, Vitanja in Konjic na jugozahodu do Ruš, Maribora in Miklavža na Dravskem polju, so značilnosti naslednje (vzorec za Zreče - samoglasniški sestav: $i$, $u$, ̀̀j, ̀̀u, é, ó, ié, uó, ó, áj, áu, á, ár):

- vsi samoglasniki so dolgi, le novonastali polglasnik po skrajšanju starih diftongov je nekoliko krajši;

- za vse samoglasnike je značilno zatezanje, pogosto tudi diftongiranje visokih dolgih $i$-jev in $u$-jev v -əj- in -əu-: hájša, zgubájli; dráugi, slàužit;

- današnja dolga $i$ in $u$ sta odraza za nekdanji ozki $e$ in $o$, nastala iz staroakutiranih $\breve{e}$ in $e$ ter kratko- in novoakutiranih -o-: líto, níč; húdla, pústit;

- dolga ozka $e$ in $o$ zastopata nosni $e$ in $Q$ ter dolgi polglasnik: grẹ́m, gọba, dẹn, vẹ́s;

- široki o je naslednik starega $a$-ja;

- stalno dolgi jat in dolgi etimološki $e$ in dolgi o sta se prek diftonga éj,óu razširila v áj, áu: dváj, pájč; máust;

- dolgi a je nastal iz kratkega $a$ : brát, šlá;

- dolgi ár je zastopnik samoglasniškega $r$.

Soglasniške premene so podobne kot v mislinjskem govoru: $l j>l$ ziẹmla, $n j>j$, jíva, zódn, sekundarna nazalizacija: mlájnko; parazitski j: vuójz, tújdi.

$\mathrm{V}$ oblikospreminjevalnih in oblikotvornih vzorcih sta mislinjski in zreški govor podobna.

\section{Značilnosti govora v Gaberkah}

Govor Gaberk spada v obmejno področje severnega dela srednjesavinjskega narečja: s severa nanj močno vpliva koroška narečna baza, z zahoda pa zgornjesavinjsko narečje.

Dolgi vokali so: $i, u$, é, ó, éj, óu, é, ó, eé, uó, á, á + ór.

Kratki naglašeni samoglasniki so: $\grave{i}, \grave{u}, \grave{u}, \grave{e}, \grave{o}, \grave{e}, \grave{\partial}, \grave{o}, \grave{a}, \grave{a}$. Silabemi so tudi t, n, m.

Vokali so lahko naglašeni na katerem koli zlogu besede: mọtka, meégla, zláto, kuósti.

Pri oblikospreminjevalnih vzorcih prevladuje nepremični naglasni tip.

Posebnosti v samoglasniškem sestavu so:

- dolga $i$ in $u$ se lahko sredi besede pred soglasnikom skrajšata;

- široki e se pogosto diftongira v eé: séstra/seéstra;

- dolgi ozki e praviloma zastopa staroakutirani jat (léto), dolgi nosni e (pẹtek, dẹtela); dolgi in novoakutirani polglasnik (lẹn, dẹn); dolgi etimološki $e$ (imẹna, nẹsu);

- dolgi ozki $o$ je naslednik dolgega nosnega $Q$, dolgega etimološkega $o$ (bọg, $n o ̛ ́ c ̌)$, novoakutiranega $o$ (vọ́la);

- diftong ej je praviloma zastopnik dolgega jata in dolgega etimološkega $e$, se pa lahko že poenoglaša v ozki e: léjt (rod. mn.), péjč;

- ou je odraz za samoglasniški ł: vóuk, póuh; 
- široki é poleg eé zastopa umično in kratko naglašene $e$-jevske vokale: peés, žeéna/žéna, kmeét, seéno;

- uo je refleks za umično naglašeni $o$ in za novoakutirani $o$ : kuóza, uósa; škuóf;

- zaokroženi á je naslednik akutiranega $a$ : krắva, čisti á pa cirkumflektiranega a: grád, král.

Kratki naglašeni, razen $i$ in $u$ po položajnem krajšanju, so nastali iz akutiranih vokalov.

Soglasniške premene so naslednje:

- sklop -vi- prehaja v -j-: prájla, postájli (koroški pojav);

- parazitski -j-: pójsla, nọjsla;

- nj > j: svíja, žiuléje;

- lj > l: vóla, plùče;

$-d n->-g n-:$ gnár;

$-d l->-g l-:$ gléjtva;

$-g>-h: b o ̣ ́ h$.

Moderna vokalna redukcija se pojavlja v končaju nedoločnika, sicer pa ob zvočnikih.

Značilni oblikoslovni dialektizmi so:

- pri samostalniku moškega spola je v mestniku ednine poleg končnice - $u$ tudi $-i$; or. ednine ž. sp. ima končnico $-i$; v pridevniški sklanjatvi je v rod. moška končnica -iga.

\section{Zaključek}

Za koroška narečja so značilni vsi splošni južnoslovanski ter splošnoslovenski razvoji in inovacije, ki jih je oblikujoči se slovenski jezik izvedel, odkar so se naši predniki naselili v Alpah, na Krasu in v Panoniji. Najpomembnejši koroški pojavi so: skrajšanje starega praslovanskega akuta in kasnejše podaljševanje; diftongizacija (12./13. stoletje) dolgega jata $\mathrm{v}$ ie in dolgega $o \mathrm{v}$ uo in kasneje $\mathrm{v}$ diftong s polglasnikom; dolgo ohranjena nazalnost obeh nosnikov; vokalizacija polglasnika v e-jevski refleks (den, meh, meša); pozno podaljševanje nezadnjih naglašenih kračin povzroči nastanek različnih odrazov za akutirane jat, $e$ in $o$; lokalno koroški so še labiovelarizacija $a \mathrm{v} o$; umik cirkumfleksa in premik v tipu babica; prehod $ł a \mathrm{v} w a$; razvoj $l j \mathrm{v} l, n j \mathrm{v} j$; okrepitev zaimkov in prislovov s členico še: ̌̌eti, štak.

V razpravi je predstavljeno glasoslovje v govorih Mežice, Črne in Javorja, kjer je prišlo do poenoglašanja dvoglasnikov tipa ie, uo, ea, oa; v govoru Šentanela, kjer se kaže vpliv podjunskega narečja na labializacijo $a$ v $o, a$ je refleks dolgega in kratkega polglasnika in nosnega $e$; v kotuljskem govoru so ohranjene vse samoglasniške in soglasniške značilnosti, opisane v teoriji o mežiškem narečju s sestavom dolgih in kratkih samoglasnikov, s švapanjem in 
štekanjem; v govoru Ojstrice nad Dravogradom se pojavljajo tudi glasoslovne značilnosti podjunskega narečja, torej se polglasnik in nosni $e_{\text {razvijeta } \mathrm{V}}$ $a$-jevski odraz, dolgi $a$ se zaokroži v široki $o$, pojavljajo se dvoglasniki ie, $u o, e a, o a$, znano je koroško švapanje in $v$ se izgovarja dvoustnično kot $w$; v govoru Pameč pri Slovenj Gradcu so samoglasniški sestavi enaki kotuljskim, izgubilo se je le švapanje.

Na Karti slovenskih narečij (1983) je mislinjski govor označen kot koroško mežiško narečje. V samoglasniškem in soglasniškem sestavu pa se pojavljajo značilni štajerski refleksi, tako npr. za dolgi jat in etimološki $e$ diftong $e j$, za dolgi o diftong ou. Za utemeljitev uvrstitve mislinjskega govora v štajersko narečno skupino so dodane značilnosti južnopohorskega zreškega govora in srednjesavinjskega govora Gaberk.

Nove dialektološke raziskave posameznih govorov dokazujejo, da koroško mežiško narečje v razvoju glasoslovja ni enotno.

\section{LITERATURA}

Tine LOGAR, 1968: Štajerska narečja. Jezik in slovstvo 13/6. Ljubljana.

- -, 1984: Slovenski dialekti - osnovni vir za rekonstrukcijo razvoja slovenskega jezika. Zagreb.

Tine LOGAR, Jakob RIGLER, 1983: Karta slovenskih narečij.

- -, 1993: Slovenska narečja. Ljubljana: Mladinska knjiga.

Fran RAMOVŠ, 1931: Dialektološka karta slovenskega jezika.

- -, 1935: Historična gramatika slovenskega jezika. VII. Dialekti. Ljubljana.

Jakob RIGLER, 2001: Zbrani spisi 1. Ljubljana.

Zinka ZORKO, 1995: Narečna podoba Dravske doline. Maribor: Kulturni forum.

- -, 1998: Haloško narečje in druge dialektološke študije. Maribor: Slavistično društvo Maribor. (Zora, 6).

VIRI

Terezija BALANT, 1995: Govor Gaberk pri Šoštanju. Diplomsko delo. Pedagoška fakulteta. Maribor.

Vanja BENKO, 1999: Živalski frazemi v Prežihovi Požganici in v mežiškem narečju. Diplomsko delo. Pedagoška fakulteta. Maribor.

Jelka KOS, 2000: Javorski govor z vzorci iz živalske frazeologije. Diplomsko delo. Pedagoška fakulteta. Maribor. 
Lea ODER, 2003: Mislinjski govor. Diplomsko delo. Pedagoška fakulteta. Maribor. Irena RUBIN SMOLAR, 2007: Govor Pameč. Diplomsko delo. Pedagoška fakulteta. Maribor.

\section{THE CARINTHIAN MEŽICA DIALECT IN VIEW OF RECENT PHONOLOGICAL STUDIES}

Carinthian dialects are characterized by all of the general South Slavic and universally Slovene developments and innovations that have taken place since the time of our ancestors' settlement in the Alps, Karst and Pannonian regions. The most important Carinthian phenomena include the shortening of the old Proto-Slavonic acute and its later lengthening; the diphthongization of the long yat into ie and of the long $o$ into $u o$ in the $12 / 13^{\text {th }}$ century and afterwards into a diphthong with a semi-vowel; nasalization of both nasals for a considerable period of time; and the vocalization of the semi-vowel into a reflex of $e$ (den, meh, meša). Also, the late lengthening of non-final stressed sort vowels entailed the occurrence of various reflexes of the acute yat, $e$ and $o$. Among other local Carinthian phenomena, we find the labio-velarizaton of $a$ into $o$, the shift of the circumflex in the type babica, the transition of $t a$ into $w a$, the development of $l j$ into $l, n j$ into $j$, and the strengthening of pronouns and adverbs through the use of the clitic $\check{s}$ e : šeti, štak. This study presents the phonology of the local dialects of Mežica, Črna and Javorje, where the diphthongs of the type $i e, u o$, ea and $o a$ changed into monophthongs. The local dialect of Šentanel reflects the influence of the Podjuna dialect on the labialization of $a$ into $o$, while $a$ is a reflex of the long and short semi-vowel and of the nasal $e$. The Kotulje local dialect has retained all of the vowel and consonant characteristics (long and short vowel systems as described in the theory of the Mežica dialect) together with so-called švapanje and štekanje. The local dialect of Ojstrica near Dravograd shows some phonological features of the Podjuna dialect, i.e. the semi-vowel and the nasal $e$ develop the $a$ reflex, the long $a$ is rounded into a broad $o$, and we witness the development of the diphthongs $i e, u o, e a$ and $o a$, the Carinthian švapanje and $v$ pronounced bilabially as w. The vowel systems in the local dialect of Pameče near Slovenj Gradec are the same as those in Kotulje, while the švapanje has been lost. The Map of the Slovene Dialects (1983) defines the Mislinja local dialect as a Carinthian Mežica dialect. Nevertheless, its vowel and consonant systems show typical Styrian reflexes, e.g. the diphthong ej for the long yat and the etymological $e$, and the diphthong ou for the long $o$. The features of the southern Pohorje dialect of Zreče and of the Middle Savinja dialect of Gaberk are presented to support the classification of the Mislinja dialect into the Styrian dialect group. Recent dialectological studies of individual local dialects prove that the Carinthian Mežica dialect is not uniform in its phonological development. 